\title{
Integrative Values of Sufism and Nationalism within Santri Communities at Pondok Pesantren Daarul Ulum wal Ḥikam Yogyakarta (Leadership and Character Building Analysis)
}

\author{
Shofiyana Nadia Fairuz \\ UIN Sunan Kalijaga \\ sofienadyaa@gmail.com
}

\begin{abstract}
:
National identity crisis emerged in the country; many pesantren understand Sufism textually, and the need to dialogue Sufism in the national context. The Pesantren of Pesantren Daarul Ulum wal Hikam Yogyakarta prepared future leaders with high moral values through the implementation of Sufism and nationalism education in an implementative way through a humanist approach. The researcher employs qualitative method for the field research. Data collection techniques are observation, interview and documentation. The data gained then is analyzed through data reduction, data presentation and conclusion making. The validity test of the research data used triangulation techniques and sources. The results showed that, Sufism values are implanted at boarding Daarul Ulum wal Hikam through several methods: (1) role models, (2) spiritual training with phases of Takhalli, Tahalli, Tajalli, and (3) story telling. The values of Sufism include: sincerity, repentance, khauf and raja', zuhud, faqir, patience, ridha, muraqabah. The sufism at this pesantren followed Sunni Sufism based on Ahlussunah wal Jama'ah. Nationalism values are inculcated through the following methods: (1) knowing the good, (2) loving the good, (3) desiring the good. Nationalism values include religious, tolerance, hard work, independent, democratic, patriotism, national spirit, communicative, peace loving, care for the environment and responsibility based on Pancasila and the 1945 Constitution. The formation of leadership character is done by integrating the values of Sufism and nationalism in teaching and learning activities, pesantren culture and self-development so that the following characters emerge: theocentric, voluntary in serving, wisdom (fatanah), simplicity, independence, altruism, sincerity, nationalism, responsibility (amanah), role modeling, moderate, visionary. The synergy of the values of Sufism and nationalism was applied through the concepts and processes of education that were organized by the pesantren. The synergy produced the values of Sufism which was nuanced by nationalism and created a new educational model namely SufismNationalism Education.
\end{abstract}

Keywords: Sufism, Nationalism, Leadership, Character Building, Pesantren 


\section{A. Introduction}

ufism as the core of moral education at Islamic boarding school (pesantren) had been dominating the curriculum of education since 15 th to 18 th century. There $\checkmark$ was a shift in the 19th and 20th from Sufism-oriented education to language and fiqh (Islamic Jurisprudence) oriented. ${ }^{1}$ The reason was the fact that Sufism was assumed to have similarities with mysticism which was no longer relevant to the condition at the time and human resources. This shifting orientation could be seen from most pesantren which tended to understand Sufism rigidly such as performing seclusion and staying away from the mundane life, particularly politics and government. Sufism should not be seen as a passive symbol for human civilization. Instead, Sufism should be understood as a solution from a different perspective. Therefore, dialogue between Sufism and modernity is essentially needed to construct a new substantive education. ${ }^{2}$

The Pesantren of Daarul Ulum wal Hikam (DAWAM) used a humanistic approach in organizing its education. The pesantren does not apply any kind of punishment (ta'ziran) so that the santri (students of pesantren) carried out various activities on their own awareness. In addition, santri had the opportunity to participate in designing learning materials according to their needs. Santri were motivated to think creatively, critically and responsibly as an effort to form leadership character in line with the vision of the Islamic boarding school i.e. "Creating noble leaders". Sufism and nationalism were developed through learning activities in classrooms or being directly practiced as an integral part of the community (live in).

Based on the above background, the study focuses on: (1) How to educate the values of Sufism and nationalism in the Pesantren Daarul Ulum wal Hikam? (2) How is the formation of leadership character conducted by the Pesantren of Daarul Ulum wal Hikam?

\section{B. The Values Of Sufism, Nationalism, and Leadership Character}

Synergy in the Great Dictionary of The Indonesian Language (KBBI) means join operation or activity. Therefore, synergy is understood as a combination of two or more elements that co-exist and complement each other in order to achieve a harmonious unity and intact. Further fundamental theories of this research are described as follows.

Mujamil Qomar, Pesantren : dari Transformasi dan Metodologi Menuju Demokratisasi Institusi, (Jakarta: Penerbit Erlangga, 2005). p. 126

2 Abdul Kadir Riyadi, Antropologi Tasawuf: Wacana Manusia Spiritual dan Pengetahuan, (Jakarta: Pustaka LP3ES, 2014). p. 102. 


\section{Values of Sufism and Nationalism}

Gardon Allport stated as quoted by Mulyana, "Values are beliefs that make a person act on the basis of his choice". Kuperman explained, "Values are normative benchmarks that influence humans in determining their choice among alternative ways of action". ${ }^{4}$ It can be concluded that value is the basis of human action that influences significantly on their quality of life as the impact of their actions and choices.

Abu Hasan asy-Syadzili describes Sufism as, "training the soul to diligently worship and return to the laws of God." Ibn Ujaibah said, "Sufism is the knowledge to know how to reach Allah, cleanse the mind from all despicable morals and beautify it with a variety of commendable morals" 6 . So that, Sufism is a science that studies how to purify soul as an effort to get closer to God.

Overall, Al Ghazali believes that there are seven values of Sufism that need to be realized in everyday life and thoughts in order to become a perfect human being (insan kamil). The seven values are ${ }^{7}$ repentance, zuhud, faqir, patience, ridha, muraqabah, khauf and raja!

The values of nationalism in developing cultural education and national character are sourced from the followings: religion; Pancasila (five principles); culture; national educational goals. ${ }^{8}$ Those sources generate nationalism values namely ${ }^{9}$ : being religious, being honest, tolerance, discipline, hard work, being creative, being independent, being democratic, having high curiosity and having spirit of nationalism.

\section{Theories of Character Building}

Simon Philips states, "character is a collection of values that lead to a system, which underlies the thoughts, attitudes, and behaviors displayed." 10 Thomas Lickona describes that character is formed from three interrelated parts; moral knowing, moral

3 Rohmat Mulyana, Mengartikulasikan Pendidikan Nilai, (Bandung: Alfabeta, 2011), p. 9.

4 Ibid.

5 Quoted from Hamid Shaqqar, "Nur at-Tahqiq" dalam Syaikh Abdul Qadir Musa, Hakekat Tasawuf, (Jakarta: Qisthi Press, 2011), p. 6.

6 Quoted from Ahmad ibn Ujaibah (died in $1266 \mathrm{H}$ ), "Mi'raj at-Tasyawwuf il Haqa'iq atTashawwuf" in Syaikh Abdul Qadir Musa, Hakekat Tasawuf, (Jakarta: Qisthi Press, 2011), p. 6.

7 Samsul Munir Amin, Ilmu Tasawuf, (Jakarta: Amzah, 2012), p. 214. See also Al Ghazali, Ihya Ulumuddin, (Indonesia: Daarul Kutub Arabiyah), IV.

8 Kementrian Pendidikan Nasional, Badan Penelitian dan Pengembangan Pusat Kurikulum, Pengembangan Pendidikan Budaya dan Karakter Bangsa: Pedoman Sekolah, (Jakarta: Badan Penelitian dan Pengembangan Pusat Kurikulum Kemendiknas, 2010), p. 8-9.

9 Kementrian Pendidikan Nasional, Badan Penelitian dan Pengembangan Pusat Kurikulum, Bahan Pelatihan Penguatan Metodologi Pembelajaran Berdasarkan Nilai-Nilai Budaya untuk Membentuk Daya Saing dan Karakter Bangsa, (Jakarta: Badan Penelitian dan Pengembangan Pusat Kurikulum Kemendiknas, 2010), p. 9-10.

10 Simon Philips, Refleksi Karakter Bangsa (Jakarta: Bumi Aksara, 2008), p.235.

Teosofia: Indonesian Journal of Islamic Mysticism, Vol. 7, No. 2, 2018 
feeling, and moral action. ${ }^{11}$ Based on the explanation above, it can be concluded that character is a realization of values by human beings that consistently affect their behavior, lifestyle, and thinking.

Doni A. Koesoema explains that character education is a personal and social effort to create a conducive environment for the growth of individual freedom. ${ }^{12}$ Character education is defined as character planting directing the learners to understand (cognitive), feel (affective) and doing good (psychomotor).

Character development in formal and non-formal education units is divided into four pillars, namely teaching and learning activities in classrooms, daily activities in the form of cultural development of formal and non-formal education units; curricular and/or extracurricular activities, as well as daily activities at home and in the community. ${ }^{13}$

Maragustam explained six strategies for character formation, that is: habituation and civilizing, moral knowing, moral feeling and loving, moral acting, moral models and repentance. ${ }^{14}$

Masnur Muslih outlines the strategy of character building in two ways, namely integration in daily activities and integration in programmed activities. ${ }^{15}$

Ratna Megawangi proposes four methods of implementing character education, namely: (1) knowing good, (2) loving the good, (3) desiring the good, and acting the good simultaneously and continuously. ${ }^{16} \mathrm{M}$. Athiyah Al-Abrasy explains several methods of character formation namely ${ }^{17}$ : (1) role model, (2) advice, commands, gentle advice, and (3) drilling. Character drilling in Sufism is done through several stages namely18: (1) takhalli (emptying oneself from despicable behavior or morals), (2) tahalli (filling or decorating oneself by familiarizing oneself with good behavior,

11 Thomas Lickona, Pendidikan Karakter: Panduan Lengkap Mendidik Siswa Menjadi Pintar dan Baik (Bandung: Nusa Media, 2013), p. 72.

12 Doni Koesoema A. Pendidikan Karakter: Strategi .., p. 194

13 Kemendiknas, Kerangka Acuan Pendidikan Karakter, (Jakarta: Direktorat Ketenagaan, Direktorat Jenderal Pendidikan Tinggi Kementrian Pendidikan Nasional, 2010), p. 26.

14 Maragustam Siregar, Filsafat Pendidikan Islam: Menuju Pembentukan Karakter Menghadapi Arus Global, (Yogyakarta: Kurnia Kalam Semesta, 2016), p. 264-271.

15 Masnur Muslih, Pendidikan Karakter: Menjawab Tantangan Krisis Multidimensional, (Jakarta: Bumi Aksara, 2011), p. 175-176.

16 Ratna Megawangi, Pendidikan Karakter, (Cimanggis: Indonesia Heritage Foundation, 2007), p. 15.

17 M.Athiyah Al-Abrasy, At-Tarbiyah Al-Islamiyah, terj. Bustami A.Gani dan Djohar Bahry, DasarDasar Pokok Pendidikan Islam, (Jakarta: Bulan Bintang, 1990), p. 113.

18 Ahmad Bangun Nasution dan Royani Harum Siregar, Akhlak Tasawuf: Pengenalan, Pemahaman dan Pengaplikasiannya disertai Biografi dan Tokoh-Tokoh Sufi (Jakarta: RajaGrafindo Persada, 2013), p. 31 
deed and moral values), (3) tajalli (loving for God and strengthening the feeling of love).

\section{Leadership Character}

Suradinata explains that leadership is an ability of a leader to control, lead, influence the thoughts, feelings or behavior of others to achieve the goals that have been set previously. ${ }^{19}$

The ideal leadership model refers to the leadership of the Prophet Muhammad. The ability of leaders to control themselves and influence others to achieve common goals by emulating the life of the prophet is called prophetic leadership. ${ }^{20}$ The prophetic leadership paradigm as described in the QS. Ali Imran: 110 includes three elements, namely: humanism (amar ma'ruf), liberation (nahi munkar) and transcendence (faith in Allah). ${ }^{21}$

As described in the Al- Quran, the leadership character of the prophet is as follows ${ }^{22}$ :

1. Being smart, analytical and critical (fatanah) as contained in QS. Al- Baqarah: 151, QS. Yusuf: 55, and QS. Yusuf: 109.

2. Tablig (being communicative), being firm, brave, honest, and standing for justice as written in the QS. Al- Baqarah: 213 and QS. At- Taubah: 33.

3. Being gentle and full of affection as narrated in QS Ali Imran: 159 and QS AlAnbiya: 107.

4. Carrying the mission of monotheism or tauhid (transendental) as contained in QS Al-A'raf: 59, and Q.S. Al- A'raf: 65, 73, 85.

\section{Concept And Implementation of Leadership Character Building Based On The Values of Sufism And Nationalism}

\section{Teaching Sufism and Nationalism Values}

Sufism is taught directly by pesantren leaders (kiai) as the highest scientific symbol in the structure of Islamic scholarship. Gus Mohamad Sobirin explained, ${ }^{23}$

19 Suradinata, Ermaya, Psikologi Kepegawaian dan Peranan Pimpinan Dalam Motivasi Kerja, (Bandung: CV Ramadan, 1995), p. 11.

20 Fryda Elsintania, "Pengaruh Kepemimpinan Profetik Dan Etos Kerja Islam Terhadap Komitmen Organisasi” dalam Prosiding Konferensi Nasional Peneliti Muda Psikologi Indonesia 2016 Vol. 1, No. 1, p. 74

21 Kuntowijoyo, "Islam Sebagai Ilmu: Epistemologi, Metodologi, dan Etika", (Yogyakarta: Tiara Wacana, 2006), p. 87.

22 Soleh Subagja, "Paradigma Nilai-Nilai Kepemimpinan Profetik: Spirit Implementasi Model Kepemimpinan di Lembaga Pendidikan Islam" dalam PROGRESIVA Vol.3 No 1. Januari-Juni 2010 , p. 36.

23 The data was gained through interview with Mohamad Sobirin, the head of the Pesantren Foundation of Darul Ulum wal Hikam, on June 18, 2017 at 20.15 in Complex 2. 
"... as we truly believe that Sufism is the basic of character education in pesantren-knowledge structure. So that character can be said, based on the epistemology of pesantren sciences, as something that can form ithminanul qolb. what is it? the calmness of the sou. That is the main purpose of our life or how life is managed, life orientation is ithminanul qolb, or in the language of psychology, the term well being - subject well being. That is what was formed, how to form it, the strategy was indeed that the curriculum was predominant, the basis curriculum was the nomenclature of Sufism. "

Sharia should be learned first before Sufism. Based on books they studied, it could be concluded that the pesantren followed Sunni Sufism such as Al Ghazali, so that the values of Sufism include: the ascetic, repentance, khauf (fear of Allah) and raja' (hopeful to Allah), needy, patient, rida (perfect contentment with God's will or decree), muraqabah (self-obsrevation). The cultivation of Sufism values in students is done through several methods, namely:

a) Exemplary Method

Exemplary method significantly impacted on students mentality. The value of zuhud, for example, is shown directly by the devotion of pesantren leader (kiai).

b) Spiritual Training Method

The training was carried out, as explained by Ahmad Bangun Nasution and Royani Harum Siregar, in the forms of:

1) Takhalli

The process is done in order to raise students or santri's awareness and knowledge about bad deed through teaching-learning activities, intensive training and regular dhikr every morning and evening as a means to bring heart closer to God.

2) Tahalli

Santri are encouraged to apply and practice the values contained in the Sufism books they study.

3) Tajalli

The kiai provides for santri guidance by strengthening the transcendental dimension and knowledge which is sourced from God.

c) Story-Telling Method

This method is carried out by the kiai by telling various events experienced by himself, his family or colleagues. Each event was described as well its ibrah (moral message) and the values related to the topic being studied so that santri understood and could relate the values to their lives.

Nationalism education was taught through discussions and study forum led by santri. Based on the observations, the researcher concluded that nationalism values were instilled as a value that increases santri's awareness of their citizenship and 
state-membership corresponding to the Pancasila ideology and the 1945 Constitution. The above mentioned values, namely: religiousness, tolerance, hard work, independent, democratic, love of the fatherland, nationalism, communicative, love peace, care for the environment and responsibility. The planting of nationalism values was carried out according to the Ratna Megawangi exposure method, namely:

1) Knowing the good

This method was carried out through nationalism discussion and study forum. The goal is, for students, to master and understand rationally about nationalism and the importance of nation and state awareness.

2) Loving the good

Santri were directed to be fond of (doing) kindness by touching Santri's emotional side. Every material of nationalism education was related to Santri's life.

3) Desiring the good

Understanding and loving good give impact on the emergence of santri's desire to do good. This was demonstrated by their participation in expressing their aspirations both within the pesantren and the community.

4) Acting the good

Knowing the good grows the love and desire of santri to do good. One of examples was that santri lived within the community so that they could observe and analyze the situation. If they found a problem, they could look for the source of the problem to formulate the best solution.

\section{Building Leadership Character}

DAWAM pesantren shapes leadership character by making a right synergy between Sufism and nationalism values in daily activities and programmed agendas as like the theory of Masnur Musleh. In details, the formation of the leadership character of santri in Pesantren DAWAM can be described as follows:

\section{a) Teaching and Learning Activities}

1) Learning Process

Teachers/ustaż taught study material based on curriculum. Besides, teachers/ ustaż could also do improvisation for their teaching methods. The steps of learning process are as follows: ${ }^{24}$

24 The data was gotten from observation to Siti Khoirotun Nisa as the chief of Pesantren DAWAM for female in his teaching planning on May 18-21, 2017 at main complex.

Teosofia: Indonesian Journal of Islamic Mysticism, Vol. 7, No. 2, 2018 
(a) Preliminary Activities

Based on the observation, the preliminary activities are: teachers/ustaz got in the classroom based on schedule, greeted students, and prayed; filled out students' attendance list; brushed up on previous materials; and delivered general learning material (basic competency).

(b) Main Activities

1. Exploration

Exploration was done through personal consultation to the teachers/ustadz. In addition, the exploration was also done in the form of questions from teachers/ustaż to santri, so that it could be concluded that exploration activities in pesantren were almost the same as learning activities in formal schools.

2. Elaboration

Guru/ustaż gave practical and/or written assignments that would be discussed in the next meeting led by students.

3. Confirmation

Teachers/ustadz confirmed learning outcomes in a short description related to the lesson material so that students were able to apply lessons learned in their daily lives.

(c) Closing Activities

Teachers/ ustaż concluded the lesson and evaluated the class by giving questions to students. Furthermore, teachers closed and recited prayers together with students.

2) Curriculum

The synergy of Sufism and nationalism values was drawn as a hidden curriculum in the learning process at pesantren DAWAM. Learning material given linked something related to nationalism to Sufism or vice versa; inserting Sufism values in nationalism.

After examining the lesson material, Qur'anic interpretation book of al Ibriz in Q.S. Al- Maidah verse 48, the kiai explained that the verse supported the idea of Indonesian principle of Bhinneka Tunggal Ika, unity in diversity. God is able to create humans in one form or color, but in reality, God creates a variety of differences. Islam also has many different religious thoughts and ijtihad methods. These differences should not be seen as the cause of conflict and disharmony among Muslims, instead, they are sunnatullah (God's will) to make human compete in doing good things.

In the context of nation and state, various differences may serve as a unifying bridge. Santri should take it that diversity comes from God, so they can 
position themselves as Muslims with the ideology of Pancasila that maintain the unity of Indonesia.

The discussion on nationalism held on a Thursday, May 4th, 2017 with the theme "Responses to Hoax to Maintain National Stability". A Santri who acted as one of the speakers highlighted the phenomenon of hoaxes in Indonesia by describing various factors causing the spread, indications, and consequences of hoaxes. The discussion ended with a description of the danger of spreading slander as stated in Al- Quran QSAl- Baqarah: 217 and QS. Al- Baqarah: 191.

Nationalism education was also taught in an informal method called "Ngaji Kebangsaan" or Nationalism Forum. Ngaji Kebangsaan invited ulama or Muslim clerics and umaro (officials of government) sit together in one forum to discuss about the diversity, nationalism, and Islam nusantara. ${ }^{25}$

The core of religious nationalism is reflected in the recitation of shalawat (poems to praise Prophet Muhammad) and the singing of Indonesian anthem together in the forum. The aim of Pengajian Kebangsaan was to teach the learners not only about Islam but also nationalism. For example, Pengajian Kebangsaan on Wednesday, May 24, 2017 discussed the theme "Maintaining the Diversity of Indonesia towards Islam Rahmatan Lil Alamin". The theme was chosen due to issues related to national problems, Islamic state, that threaten the unity of Indonesia. This showed the concern of pesantren for public knowledge about the country's problems seen from Muslim scholars and the government point of views. The speakers were representatives of Islamic organizations, governments, employers and also muslim clerics. ${ }^{26}$

\section{b) The Culture of Pesantren}

The culture of pesantren includes the culture of living modest, independent, sincere, democratic, friendly and responsible.

Living modesty is shown by their reasonable way of meeting their needs and their proportional speaking, doing, and eating. Modesty represents the values of zuhud and ridho. Santri were taught not to put worldly or mundane life as their highest priority. At the same time, modesty contained the values of being faqir, no desire or willingness to possess wealth and authority excessively so that he or she could easily take off the position for the community interests.

Independence was shown by not relying on others. The pesantren encouraged

25 The information is gained through interview with Muhammad Syarifuddin Ghozali as the department of education on June 10, 2017 at 19.30 in Central DAWAM (PP DAWAM I).

26 The data was sourced online news written by Irwan Kelana with the title "Ponpes Dawam Gelar Pengajian Kebangsaan", in https://www.republika.co.id Thursday, Mey 25, 2017 at 20.37, accessed on July 1, 2017 at 20.40 WIB.

Teosofia: Indonesian Journal of Islamic Mysticism, Vol. 7, No. 2, 2018 
santri to try to meet their own needs and not to always depend on their parents. Independence in terms of economic is also an important aspect of life. In this pesantren, santri had to manage a number of pesantren economic enterprises such as: Rumah Entrepreneur Indonesia (REI); Dawam Information Technology (DTI) and KOPSINDO (Koperasi Santri Indonesia). Some santri also managed independent businesses such as el-Hawa Souvenir, Esensi Coklat, Angkringan etc. The kiai gave insight into the attitude of zuhud and faqir. Zuhud does not mean to reject completely worldly life. On the other hand, Zuhud placed economic and political activities at the root of humanism values as a form of devotion to God.

Santri's sincerity was shown by the fact that their motivation of praying, working, studying, and teaching is only for God. DAWAM pesantren is a non-benefit boarding school that does not take some amount of money from its students. It is a form of applicative sincerity that is taught through the exemplary of kiai. Santri are encouraged to do good things without hoping for any returns. Other examples of Santri's sincerity are teaching at School for Reading the Qur'an (TPA) at village and being involved in social activities with the local communities. The santri are encouraged to do Sadaqah (charity) with their energy, thought and prayers according to their ability without thinking about material benefits.

Another interesting habit of DAWAM santri is to greet each other. Santri are accustomed to greeting and saying salam when meeting other santri both inside and outside the pesantren environment. Santri understood the virtues of salam. Saying salam and greetings is a symbol of Muslim identity. The kiai explained the importance of saying salam and answering greetings in the study of Al Ibris Chapter An-Nisa: 86.

This pesantren is also democratic. It can be seen from the discussions and study forum in the learning activities at pesantren Dawam. Santri take part in the formulation of the curriculum with the education department so that they could design the study concept to reach the objectives of their study at the pesantren. ${ }^{27}$

This process lets santri think about their prospects in the next few years. On another occasion, santri exchanged ideas and thought directly with kiai related to their studies. Santri used to think critically and creatively and was encouraged to be tolerant to others.

The culture of responsibility is reflected in santri's awareness of their responsibility and obligations. An interesting point from the DAWAM Pesantren is their humanist upbringing. The pesantren did not apply punishment (ta'ziran) and fine. This is intended to develop santri's spirit of leadership because all of their actions

27 The data is gathered from Interview with KH. Ahmad Sugeng Utomo as the Kyai/Kiai of Pesantren DAWAM and Gus Mohamad Sobirin as the head of The Pesantren Foundation on June 18, 2017 at 20.15 in Complex 2. 
are supervised directly by God and every individual's activities and deed will be counted in the hereafter. ${ }^{28}$

\section{c) Self Development}

1. Routine Activities

The pesantren conducted some routine activities to form a transcendental character of santri. After doing further observation, these activities contain Sufism values as well as nationalism values. Here are the routine activities at the DAWAM Pesantren:

Table 4.0

Daily Routine Activities at PP.DAWAM

\begin{tabular}{|c|c|c|c|}
\hline No & Activity & Sufism Values & Nationalism Values \\
\hline 1 & $\begin{array}{l}\text { Prayers } \\
\text { Congregation }\end{array}$ & $\begin{array}{l}\text { Ikhlas (sincere), zuhud (not } \\
\text { preoccupied by material } \\
\text { things), raja (expectation) } \\
\text { and khouf (fear), patients, } \\
\text { rida (perfect contentment), } \\
\text { muraqabah, taubat } \\
\text { (repentance). }\end{array}$ & $\begin{array}{l}\text { Religious, responsibility, } \\
\text { independent, peace- } \\
\text { loving, tolerance, spirit } \\
\text { of nationalism. }\end{array}$ \\
\hline 2 & $\begin{array}{l}\text { Reciting the whole } \\
\text { Al-Quran }\end{array}$ & $\begin{array}{l}\text { Ikhlas, zuhud, raja' and } \\
\text { khouf, patient, muraqabah, } \\
\text { taubat. }\end{array}$ & $\begin{array}{l}\text { tolera } \\
\text { spirit }\end{array}$ \\
\hline 3 & $\begin{array}{l}\text { Manaqiban (reciting } \\
\text { the biography of } \\
\text { Syaikh Abdul Qadir) }\end{array}$ & $\begin{array}{l}\text { Ikhlas, zuhud, raja' and } \\
\text { khouf, sabar, rida, } \\
\text { muraqabah, taubat. }\end{array}$ & $\begin{array}{l}\text { bility, } \\
\text { oving, } \\
\text { l. }\end{array}$ \\
\hline 4 & $\begin{array}{l}\text { Tahlil (a form of } \\
\text { dhikr by uttering } \\
\text { specific sentences) }\end{array}$ & $\begin{array}{l}\text { Ikhlas, zuhud, raja' and } \\
\text { khouf, sabar, rida, } \\
\text { muraqabah, taubat. }\end{array}$ & $\begin{array}{l}\text { bility, } \\
\text { oving, } \\
\text { a. }\end{array}$ \\
\hline 5 & $\begin{array}{l}\text { Sholawat Nariyah- } \\
\text { an. }\end{array}$ & $\begin{array}{l}\text { Ikhlas, zuhud, raja' and } \\
\text { khouf, sabar, muraqabah, } \\
\text { taubat. }\end{array}$ & $\begin{array}{l}\text { Religious, responsibility, } \\
\text { tolerance, peace-loving, } \\
\text { spirit of nationalism. }\end{array}$ \\
\hline 6 & Mujahadah & $\begin{array}{l}\text { Ikhlas, zuhud, raja' and } \\
\text { khouf, sabar, rida, } \\
\text { muraqabah, taubat. }\end{array}$ & $\begin{array}{l}\text { Religious, responsibility, } \\
\text { tolerance, peace-loving, } \\
\text { spirit of nationalism. }\end{array}$ \\
\hline 7 & $\begin{array}{l}\text { Maulid Diba and } \\
\text { Barzanji }\end{array}$ & $\begin{array}{l}\text { Ikhlas, zuhud, raja' dan } \\
\text { khouf, patient, muraqabah, } \\
\text { taubat. }\end{array}$ & $\begin{array}{l}\text { Religious, responsibility, } \\
\text { tolerance, peace-loving, } \\
\text { spirit of nationalism. }\end{array}$ \\
\hline 8 & $\begin{array}{l}\text { 'an (weekly deep } \\
\text { aning) }\end{array}$ & $\begin{array}{l}\text { Ikhlas, zuhud, faqir, sabar, } \\
\text { rị̣.a. }\end{array}$ & $\begin{array}{l}\text { Religious, responsibility, } \\
\text { tolerance, peace-loving, } \\
\text { care for nature }\end{array}$ \\
\hline
\end{tabular}

28 The data is souced from interview with Muhammad Syarifuddin Ghozali as the member of Education Department on June 10, 2017 at 19.30 in Central DAWAM (PP DAWAM I).

Teosofia: Indonesian Journal of Islamic Mysticism, Vol. 7, No. 2, 2018 


\section{Programmed Activities}

Programmed activities provided santri opportunities to express their skills, talents and interests. These activities are as follows:

Table 4.1

Programmed Activities at PP. DAWAM

\begin{tabular}{|c|c|c|c|}
\hline No & Activities & Sufism Values & Nationalism Values \\
\hline 1 & $\begin{array}{l}\text { Martial Arts of Persaudaraan } \\
\text { Setia Hati Terate (PSHT) }\end{array}$ & $\begin{array}{l}\text { Ikhlas, zuhud, } \\
\text { patient, rịda. }\end{array}$ & $\begin{array}{l}\text { Tolerance, hard work, } \\
\text { peace-loving, nationalism. }\end{array}$ \\
\hline 2 & Indoor football & $\begin{array}{l}\text { Zuhud, sabar, } \\
\text { rị̣a. }\end{array}$ & $\begin{array}{l}\text { Tolerance, hard work, } \\
\text { peace-loving, nationalism. }\end{array}$ \\
\hline 3 & Khitobah (speech) & $\begin{array}{l}\text { Ikhlas, zuhud, } \\
\text { patient, riḍ. }\end{array}$ & $\begin{array}{l}\text { communicative, hard } \\
\text { work, peace-loving, } \\
\text { nationalism. }\end{array}$ \\
\hline 5 & Entrepreneurship & $\begin{array}{l}\text { Ikhlas, zuhud, } \\
\text { faqir, raja' and } \\
\text { khouf, patient, } \\
\text { riḍa, muraqabah. }\end{array}$ & $\begin{array}{l}\text { Hard work, } \\
\text { communicative, } \\
\text { independent, nationalism, } \\
\text { responsible. }\end{array}$ \\
\hline 6 & $\begin{array}{l}\text { Societal organizations such } \\
\text { as JPMI (Jaringan Pemimpin } \\
\text { Muda Indonesia, Indonesian } \\
\text { Youth Leaders Network), } \\
\text { BANKOR PBN (Koordinator } \\
\text { Penggerak Budaya, } \\
\text { Coordinating Body for } \\
\text { Cultural Movement). }\end{array}$ & $\begin{array}{l}\text { Ikhlas, zuhud, } \\
\text { raja' and khouf, } \\
\text { patient, riḍa, } \\
\text { muraqabah. }\end{array}$ & $\begin{array}{l}\text { Hard work, } \\
\text { communicative, } \\
\text { democratic, nationalism, } \\
\text { responsible. }\end{array}$ \\
\hline
\end{tabular}

Pesantren has its own ways to run its activities. One of them is by having a large writing as a reminder for santri about the principles and manners of being a santri namely: ${ }^{29}$

"(1) santri iku ngilmu ora nggo ngilmu, tapi ngamal, ngajio tur lakoni kanthi sak mesthine!; (2)santri iku nganggo klambi, klambine iku jenenge akhlak, nggo o iku klambi nek endi wae!; (3)santri iku kudu dadi pemimpin, dadio pemimpin marang awakmu, nembe marang liyamu!; (4)santri iku kudu mulyo, corone.. hormatio awakmu kanti liyamu; (5)santri iku ojo mung ngaji syari'at bloko, kudu thoriqot lan haqiqote!; (6)santri iku sejatine santri yen wis manfaati kanggo liyane?'.

"(1) For santri, science is not for science, but for application, learn and do properly what you learn!; (2)santri wear cloth, and santri's cloth is called

29 The data was gained from the profile book of Pondok Pesantren Daarul Ulum wal Hikam (PP. DAWAM), presented and written by the head of Pesantren Foundation, Gus Mohamad Sobirin, entitled Profil Pondok Pesantren Daarul Ulum wal Hikam, (Yogyakarta: Yayasan Daarul Ulum Wal Hikam., 2012), p. 31. 
akhlak (good behaviour), wear that cloth anywhere!; (3)santri must be a leader, be the leader of yourselves, then others!; (4)santri must be respected, how? Respect yourselves by respecting others; (5) santri don't only learn syari'at (Islamic Jurisprudence), but also thoriqot and haqiqat!; (6)santri is called a real santri when he or she can be a useful person for others?'.

The Kiai encouraged santri to do counseling about their personal matters, such as their goals and dreams. Kiai's exemplary behaviour that is doing everything in accordance with the values taught plays pivotal role in the process of character building of santri.

Based on the explanation above, it can be concluded that the character building strategies used are:

a. Habituation and civilizing the santri

This strategy is proved by the habituation of nationalism and Sufism values through the routine and programmed activities. The activities are a reflection of the values with the vision and mission of the pesantren as a means of forming the santri's character.

b. Moral knowing

This strategy is implemented in the DAWAM Pesantren in learning activities through the study of the books used in the learning process.

c. Moral feeling and loving

This strategy is implemented in learning activities which are related to the context of everyday life, so that santri can relate the values they study with their daily lives

d. Moral acting

Santri is directed to play an active role in business, community organizations and various nationalism activities to apply the values they learn.

e. Moral model

This strategy can be clearly seen from the kiai as the role model for santri in terms of knowledge, and action. Exemplary is the most effective strategy in delivering virtue values to santri.

f. Repentance (returning back to Allah after doing sins).

The strategy of repentance was represented through encouragement to contemplate and do self evaluation about the bad deeds you have done. The activities of pesantren become a means to get closer to God and filling ourselves with values of virtues

Based on DAWAM Pesantren activities, there are three types of santri namely santri as entrepreneurs, santri as organizers and santri active in social activities. The three santri identities are representations of santri future leadership 
in three fields namely economic, organizational and social sectors. The leadership characteristics that appear in the three are as follows:

a. Theocentric

All activities are considered as worship. This character can be seen from several things: first, santri's paradigm which orientates all actions because of God whether in the pesantren environment, management of economic institutions, organizational movements, or their participation in society.

Second, santri always wear polite cloth both in pesantren and campus according to syara' ethics. Third, gentle and polite speaking. Fourth, the santri tried to complete their work without thinking of any compensation.

b. Willing to Serve

This character can be seen from the persistence of santri in carrying out their duties both in pesantren's business, organizations and social activities. Santri tried to find out solutions to problems they encountered during the process of serving the community.

c. Wisdom (Fațanah)

This character is seen from santri who set forth tabayyun (clarification) and who always consider everything based on its mashlahah (benefit) and madarat (drawbacks)

d. Simplicity

Simplicity is seen from the life of santri who are not excessive when living in boarding schools/ pesantren.

e. Independence

The independence of the santri appears from their life and thought. Santri are accustomed to managing time and money to meet their needs. Pesantren develops santri's entrepreneurship through pesantren and individual businesses.

f. Altruisme

Prioritizing public good rather than personal interests is the attitude of santri gained from their togetherness in everyday life. Santri used to live on cord and harmony in pesantren which has a diverse community.

g. Sincerity/ikhlas

This behaviour is obtained from the conditioning and exemplary of the kiai. Everything is done for the sake of God both in following pesantren activities and in personal activities and behavior.

h. Responsibility (Amanah)

Humanist approach is used to encourage santri to be responsible over everything they do. This approach rose santri's awareness that they should be responsible of 
all their actions in the hereafter. Santri obey Pesantren's activities and regulations without any pressure and coercion.

i. Nationalism

This attitude arose from santri's active involvent at various events and nationalism movements as a form of their concern over the condition of the country.

\section{j. Muhasabah}

Muhasabah here is not limited to self-reflection over our bad or good deed, but muhasabah extends to the level of self-development while living in a social community. Santri understands that good social reconstruction starts from oneself.

k. Moderation

Living coexistence with various social and cultural backgrounds broadens the horizons of the santri. Santri used to appreciate differences of opinion, not easily blame others and not get caught up in fanaticism.

1. Visionary

Santri design their study materials and subjects studied according their needs so that santri get used to have a future vision in their paradigm.

Synergy between Sufism and nationalism values produces santri's spiritual quotient. This intelligence leads santri to construct the paradigm of religious multiculturalism in the national context. The values gained from the synergy are explained as follows:

a. Repentance

Repentance is understood as awareness and understanding that everything has potentially positive and negative effects on national condition so that santri have a sense of nationalism as the best effort to do spiritual struggle for Allah.

b. Khauf and Raja'

This value grows into being afraid of doing bad things but daring to defend the country. Santri tried to respect the rights of others and obey the rules of the country's constitution as an effort to maintain the unity of the nation.

c. Zuhud

The value of zuhud in the national context is the spirit of serving the country because the land where we live today is a gift from God with its all conditions and problems.

d. Faqir

Faqir means not demanding more money and wealth. Faqir, instead, is satisfied feeling with what they have. Faqirvalues underline the act of refraining from everything not right so as to minimize acts of corruption.

Teosofia: Indonesian Journal of Islamic Mysticism, Vol. 7, No. 2, 2018 
e. Patience

By this value, santri are not hasty in addressing differences, so santri was able to control themselves against something he likes or hates.

f. Ridha

Ridha is interpreted as being satisfied with all God's gifts including the gift of living in the Indonesia geographical area. This value underlies a person to find wisdom and benefit in every condition to form positive and passionate mentality to keep the unity of Indonesia.

g. Muraqabah

Muraqabah avoids rashness in dealing with various things because absolute truth belongs to Allah alone. Things labeled as bad can be of good value in another perspective.

Several supporting factors for the success of nationalism-Sufism education in the DAWAM Islamic Boarding School are; an educational environment with conducive nationalism awareness, available facilities which are free of charge, as well as ustaż and competent presenters in their fields. The inhibiting factors are; a lack of intensive evaluation and supervision in all rooms of the boarding schools due to busy kiai; the limited space for activity because the Islamic boarding school is located within the community housings.

Pondok Pesantren Daarul Ulum wal Hikam synergistically relates the substantive value of Sufism with the context of Indonesian nationalism. The boarding school also succeeded in creating the model of Nationalism-Sufism education. This educational model strengthens the quality of the santri's character as the moral guard who is active in the social, economic, political and government spheres to promote unity, peace and law and order of the Indonesian State.

\section{Concluding Remarks}

Sufism values are taught in the Pesantren of Daarul Ulum wal Hikam through the methods of: (1) role models, (2) Spiritual training with the stages of Takhalli, Tahalli, Tajalli, and (3) telling stories. The values of Sufism include: sincere, repentance, khauf and roja, zuhud, faqir, patient, ridha, muraqabah. The Sufism follows Sunni school and based on Ahlussunah wal Jama'ah thought. Nationalism values are inculcated through methods: (1) knowing the good, (2) loving the good, (3) desiring the good. Nationalism values include religious, tolerance, hard work, independent, democratic, patriotism, national spirit, communicative, peace loving, environmental care and responsibility based on Pancasila and the 1945 Constitution.

The leadership character of santri of Daarul Ulum wal Ḥikam Islamic Boarding School students refers to the concept of prophetic leadership. The formation of 
leadership character is carried out by integrating the values of Sufism and nationalism in teaching and learning activities, pesantren culture and self-development so that the following characters emerge: theocentric, voluntary in serving, wisdom (fatanah), simplicity, independence, altruism, sincerity, nationalism, responsibility, rolemodeling, moderate, visionary. The Pesantren of Daarul Ulum wal Hikam synthesized Sufism and nationalism into a new educational model namely "Nationalism-Sufism" as a solution to the crisis of moral, character and national identity as a result of the less comprehensive contemporary Islamic understanding in responding to Islamic and humanitarian problems.

The Education Model of Nationalism-Sufism at Pondok Pesantren Daarul Ulum wal Hikam (PP. DAWAM) is very applicable as an alternative way for pesantren and other educational institutions. This is due to the combination of understanding and appreciation to Sufism with strong value of nationalism. This combination has a positive effect on the integrity of the nation. 


\section{Bibliography}

Al-Abrasy M.Athiyah, At-Tarbiyah Al-Islamiyah, terj. Bustami A. Gani dan Djohar Bahry. Dasar-Dasar Pokok Pendidikan Islam. Jakarta: Bulan Bintang, 1990.

Amin, Samsul Munir. Ilmu Tasawuf. Jakarta: Amzah, 2012.

Ermaya, Suradinata. Psikologi Kepegawaian dan Peranan Pimpinan Dalam Motivasi Kerj. Bandung: CV Ramadan, 1995.

Fattah, Nanang. Landasan Manajemen Pendidikan. Bandung: Rosdakarya, 1996.

Kementrian Pendidikan Nasional, Badan Penelitian dan Pengembangan Pusat Kurikulum. Bahan Pelatihan Penguatan Metodologi Pembelajaran Berdasarkan Nilai-Nilai Budaya untuk Membentuk Daya Saing dan Karakter Bangsa. Jakarta: Badan Penelitian dan Pengembangan Pusat Kurikulum Kemendiknas, 2010.

Kementrian Pendidikan Nasional. Kerangka Acuan Pendidikan Karakter. Jakarta: Direktorat Ketenagaan, Direktorat Jenderal Pendidikan Tinggi Kementrian Pendidikan Nasional, 2010.

Kementrian Pendidikan Nasional, Badan Penelitian dan Pengembangan Pusat Kurikulum. Pengembangan Pendidikan Budaya dan Karakter Bangsa: Pedoman Sekolah. Jakarta: Badan Penelitian dan Pengembangan Pusat Kurikulum Kemendiknas, 2010.

Koesoema A, Doni. Pendidikan Karakter: Strategi Mendidik Anak di Zaman Global. Jakarta: Grafindo, 2007.

Kuntowijoyo. Islam Sebagai Ilmu: Epistemologi, Metodologi, dan Etika. Yogyakarta: Tiara Wacana, 2006.

Lickona, Thomas. Pendidikan Karakter: Panduan Lengkap Mendidik Siswa Menjadi Pintar dan Baik. Bandung: Nusa Media, 2013.

Megawangi, Ratna. Pendidikan Karakter. Cimanggis: Indonesia Heritage Foundation, 2007.

Mulyana, Rohmat. Mengartikulasikan Pendidikan Nilai. Bandung: Alfabeta, 2011.

Musa, Abdul Qadir. Hakekat Tasawuf. Jakarta: Qisthi Press, 2011.

Muslih, Masnur. Pendidikan Karakter: Menjawab Tantangan Krisis Multidimensional. Jakarta: Bumi Aksara. 2011.

Nasution, Ahmad Bangun dan Royani Harum Siregar. Akhlak Tasawuf: Pengenalan, Pemahaman dan Pengaplikasiannya disertai Biografi dan Tokoh-Tokoh Sufi. Jakarta: RajaGrafindo Persada, 2013. 
Philips, Simon. Refleksi Karakter Bangsa. Jakarta: Bumi Aksara, 2008.

Qomar, Mujamil. Pesantren: dari Transformasi dan Metodologi Menuju Demokratisasi Institusi. Jakarta: Penerbit Erlangga, 2005.

Riyadi, Abdul Kadir. Antropologi Tasawuf: Wacana Manusia Spiritual dan Pengetahuan. Jakarta: Pustaka LP3ES, 2014.

Siregar, Maragustam. Filsafat Pendidikan Islam: Menuju Pembentukan Karakter Menghadapi Arus Global. Yogyakarta: Kurnia Kalam Semesta, 2016.

Sobirin, Mohamad. Profil Pondok Pesantren Daarul Ulum Wal Hikam. Yogyakarta: Yayasan Daarul Ulum Wal Hikam, 2012.

\section{Journal Article:}

Elsintania, Fryda, "Pengaruh Kepemimpinan Profetik Dan Etos Kerja Islam Terhadap Komitmen Organisasi" dalam Prosiding Konferensi Nasional Peneliti Muda Psikologi Indonesia 2016 Vol. 1, No. 1: 71-78.

Subagja, Soleh, "Paradigma Nilai-Nilai Kepemimpinan Profetik: Spirit Implementasi Model Kepemimpinan di Lembaga Pendidikan Islam), PROGRESIVA Vol.3

\section{Website/Newspaper:}

Kelana, Irwan, "Ponpes Dawam Gelar Pengajian Kebangsaan", in https://www.republika.co.id Thursday, accessed on July 1, 2017 at $8.40 \mathrm{pm}$. 